\title{
TIPE MEDIASI IBU RUMAH TANGGA TERHADAP KESELAMATAN BERINTERNET ANAK DAN REMAJA
}

\author{
Inasari Widiyastuti \\ inasoo1@kominfo.go.id \\ Balai Pengkajian dan Pengembangan Komunikasi dan Informatika (BPPKI) Yogyakarta
}

\begin{abstract}
The biggest of internet user is in the productive ages, most of them are children and teenagers. They are the Internet of Things's (IoT) Generation who have the ability to adapt of technology because of being born in the high technology era. Children's internet activities tend to be supported and facilitated by the environment, especially families. The aim of this research is to find out the digital literacy and medition type of housewives. The mediation strategy is an effort that is appropriate to the activities of children and teenager using handset and internet. The survey was conducted on housewives of Internet Safety Online workshop participant in four districts in DI. Yogyakarta. Restrictive mediation is applied to housewives at every level of childhood education from the youngest up to. However, mothers do not apply many types of mediation in teenagers. Discussion, as a form of active mediation, applied as protecting effort in the housewives's inability of digital literacy. Co-use mediation and technical mediation are not overused. Only a small number of housewives accompany children when using handset or accessing internet.
\end{abstract}

\begin{abstract}
Abstrak
Penggunaan internet terbesar berada di usia produktif, sebagian besar di antara mereka adalah anak dan remaja. Mereka adalah generasi Internet of Things (IoT) yang memiliki kemampuan beradaptasi dengan teknologi karena terlahir dalam paparan teknologi maju. Aktivitas anak berinternet cenderung didukung dan difasilitasi oleh lingkungan, terutama keluarga. Penelitian ini bertujuan untuk mengetahui literasi digital dan tipe mediasi yang diterapkan ibu rumah tangga. Strategi mediasi adalah upaya perlindungan yang diberikan terhadap aktivitas anak dan remaja menggunakan gawai dan berinternet. Survey dilakukan pada ibu rumah tangga peserta pelatihan Internet Safety Online di empat kabupaten di DI. Yogyakarta. Mediasi restriktif diterapkan ibu rumah tangga pada setiap jenjang pendidikan anak mulai dari termuda hingga tertua. Meski demikian, ibu tidak banyak menerapkan berbagai tipe mediasi pada remaja. Diskusi, sebagai bentuk mediasi aktif diterapkan ibu sebagai upaya perlindungan di tengah ketidakmampuan literasi digitalnya. Mediasi co-use dan mediasi teknis tidak terlalu sering digunakan. Hanya sebagian kecil ibu mendampingi anak ketika menggunakan gawai atau mengakses internet.
\end{abstract}

Keywords: Parental Mediation Children, Safety Online 


\section{PENDAHULUAN}

Seberapa dini seorang anak untuk terlalu dini menggunakan dan memiliki telepon cerdas serta mengakses internet bukanlah isu yang penting lagi. Pada kenyataannya, anak telah bersentuhan dengan teknologi informasi dan komunikasi (TIK) bahkan sebelum mereka sempurna berjalan. Pengguna terbesar internet di usia produktif dipenuhi oleh anak dan remaja. Livingstone, Haddon, Görzig, \& Ólafsson (2011) mencatat 93\% anak usia 9-16 tahun telah aktif online setiap minggunya. Mereka mulai mengakses internet sejak usia 7 hingga 8 tahun. Pada usia 9 tahun, anak telah memiliki akun dan aktif di media sosial. Pada mulanya, anak hanya menggunakan gawai untuk bermain kemudian mengakses internet. Kemampuan dalam menggunakan dan mengakses TIK meningkat seiring bertambahnya usia. Meskipun anak belum memiliki kemampuan pemahaman persepsual, simbolik, dan motorik yang baik, anak bahkan bayi telah memiliki ketertarikan terhadap konten media. Kemampuannya tersebut dipersepsikan dan dinterpretasikan sesuai dengan kapasitas gagasan sosial yang dimilikinya (Nikken \& Schols, 2015). Kesulitannya dalam menggunakan aplikasi di gawai seperti menyentuh, mengusap, membaca, dan mendengar instruksi, tidak menghalangi anak untuk tetap termotivasi menggunakan.

Anak jaman kini terlahir pada generasi milenial dan post-milenial. Mereka mampu menggunakan teknologi sejak usia dini, nyaman menggunakan, dan aktif di media sosial. Mereka adalah iGen atau generasi yang akrab dengan Internet of Things (IoT) yang beraktivitas dengan teknologi terkini dan familiar dengan belanja online (Dorsey, 2016; Howe \& Nadler, 2012). Anak dan remaja memiliki motivasi berinternet untuk mencari informasi, terhubug dengan teman, dan sebagai media hiburan (Kemkominfo, 2014). Aktivitas anak paling besar ketika online adalah mengerjakan tugas sekolah dan bermain, diikuti dengan menonton klip video, percakapan instan, mengirim gambar, dan menggunakan webcam (Livingstone, Haddon, Görzig, \& Ólafsson, 2011). Dari aktivitasnya, lingkungan mempengaruhi anak untuk terpapar TIK. Entahkah lingkungan rumah, pertemanan, hingga sekolah. Anak, tidak dengan sendirinya bisa menggunakangawai danmenjelajah internet. Kemampuan mereka muncul karena adaptasi dengan lingkungannya, melihat, mencoba, dan meniru. Anak cenderung didukung dan difasillitasi, terutama oleh orang tua.

Pembicaraan tentang ijin memiliki gawai bagi anak lebih penting dibicarakan dalam keluargadibanding tentangijin mendapatkan lisensi mengemudi. Menurut Nick Vanney (VP of Consumer Intel Security, http://tekno. liputan6.com), orang tua memfasilitasi anak dengan gawai dan menganggapnya sebagai media pembelajaran dan hiburan. Sayangnya, fasilitas yang diberikan itu kurang didukung dengan pengarahan dan pengawasan. Padahal, jika dibiarkan, anak dapat terpapar konten negatif baik secara sengaja maupun tidak sengaja yang dapat mengganggu tumbuh kembang dan pembentukan karakter. Intel Security melaporkan bahwa $79 \%$ orang tua sebenarnya khawatir dengan aktivitas anak berinternet dan hanya 6o\% saja yang memantau aktivitas anak berinternet. Sedangkan ICT WATCH menemukan hanya $38,5 \%$ orang tua yang berdiskusi dengan anak tentang aktivitas berinternet. Rendahnya kepedulian, pengawasan, dan pengarahan dari orang tua tentunya sangat mengkhawatirkan.

Gawai dan internet dapat berdampak negatif bagi anak. Anak menjadi malas bergerak, kemampuan bersosialisasi menurun, sulit berkonsentrasi di dunia nyata, dan cepat puas dengan informasi atau pengetahuan yang didapat (tidak melakukan penelusuran mendalam dan atau cek silang) (Ameliola \& Nugraha, 2013). Selain itu, anak mudah terpapar risiko penggunaan internet meliputi risiko tindakan agresif (perundungan, stalking, permusuhan sebaya), risiko seksual (konten pornografi, grooming, sexting, kekerasan seksual), risiko nilai budaya (rasisme, radikalisme, konten kebencian), dan risiko komersil seperti penyalahgunaan data pribadi (Livingstone et al., 2011). KPAI (Komisi Perlindungan 
Anak dan Perempuan) mencatat jumlah anak korban pornografi dan kejahatan online di tahun 2015 telah mencapai 1.022 anak. Kejahatan tersebut meliputi korban kekerasan seksual online, objek CD pornografi, dan prostitusi anak online. Yang menyedihkan adalah, anak bukan hanya sebagai korban kejahatan online tetapi juga sebagai pelakunya. Kejahatan anak berbasis siber menempati urutan ketiga setelah kasus anak berhadapan dengan hukum dan kasus keluarga serta pengasuhan alternatif. Menurut KPAI pula, faktor pemicu kejahatan online adalah lemahnya upaya perlindungan dari negara dan keluarga. Pembiaran oleh orang tua menjadi pemicu utama.

Orang tua dihadapkan pada tantangan akan dampak negatif media baru terhadap perilaku, sikap, dan keselamatan anak (Livingstone \& Helsper, 2008). Lingkungan media dan komunikasi berkembang sangat cepat dan sulit diikuti orang tua. Keduanya terlahir pada generasi yang berbeda. Bagi orang tua, kurangnya keahlian teknis atau literasi media dan informasi menjadi penghambat untuk melakukan mediasi bagi aktivitas anak menggunakan dan mengakses TIK. Secara teknis, hanya sedikit orang tua yang menyaring konten serta melacak kembali website yang dikunjungi anak (Livingstone et al., 2011). Leung dan Lee (2012) menegaskan pentingnya literasi media dan informasi sebagai tameng untuk melindungi diri dari risiko simpton adiksi internet dan kejahatan online. Semakin tinggi tingkat literasi seseorang maka akan semakin rendah risiko internet yang dialami. Kemampuan untuk mengakses media merujuk pada kemampuan untuk menentukan konten media yang sesuai dengan kebutuhan dan menghindar dari konten media yang tidak dibutuhkan (Kunandar, 2014). Maka, selain kemampuan teknis, orang tua perlu memiliki literasi struktur sosial dan literasi kritis dalam menggunakan dan mengakses TIK. Literasi ini penting untuk memediasi anak dengan TIK.

Teori mediasi orang tua berpendapat bahwa orang tua menggunakan strategi komunikasi interpersonal yang berbeda dalam usaha mereka untuk menengahi dan megurangi dampak negatif media dalam kehidupan anak-anak mereka (Clark, 2011). Mediasi merupakan bentuk pengawasan orang tua meski tidak sepenuhnya menurunkan anak dari risiko negatif online (Livingstone \& Helsper, 2008). Di saat orang tua berupaya mencegah paparan efek negatif, anak justru termediasi oleh lingkungan dan rekan sebaya. Anak tidak dapat dibebaskan dari interaksi dengan TIK. Sifat penggunaanya yang dipersonalisasi menjadikan tugas orang tua menjadi sulit (Livingstone et al., 2011). Kondisi ini akan semakin sulit karena anak dapat bukan selaku sasaran kejahatan online di rumah, mereka bisa mendapatkannya di luar rumah karena internet bersifat ubiquitous atau dapat diakses di mana pun dan kapan pun (Leung \& Lee, 2012). Meski demikian, terdapat beberapa gaya mediasi yang diterapkan untuk melindungi anak yaitu mediasi restriktif (restrictive mediation), mediasi aktif (active mediation), mediasi penggunaan bersama (co-use) supervise (supervision), dan mediasi teknik (technical mediation (Clark, 2011; Fikkers, Piotrowski, \& Valkenburg, 2017; Leung \& Lee, 2012; Nikken \& Schols, 2015). Persoalan risiko adiksi perangkat TIK dan internet berlaku global. Penelitian ini bertujuan untuk mengetahui literasi internet dan tipe mediasi yang diterapkan ibu rumah tangga di DI. Yogyakarta, khususnya di 4 (empat) kabupaten, terkait aktivitas anak menggunakan perangkat TIK dan berinternet.

Studi tentang tipe mediasi orang tua terhadap penggunaan media oleh anak telah banyak dilakukan dalam rangka meninjau mediasi yang efektif untuk melindungi dari pengaruh negatif media, baik itu televisi, multimedia, maupun internet. Namun, perilaku mediasi yang diterapkan banyak dikaitkan dengan penggunaan televisi dan permainan multimedia oleh anak, masih sedikit meninjaunya dari penggunaan internet (Collier et al., 2016). Jika pada masa penggunaan televisi banyak dikenal 3 (tiga) macam tipe mediasi yaitu mediasi restriktif, aktif, dan co-use, maka di era media baru 
muncul tipe mediasi baru yaitu mediasi teknik (Clark, 2011; Fikkers et al., 2017; Leung \& Lee, 2012; Livingstone \& Helsper, 2008; Nikken \& Schols, 2015).

Menurut Valkenburg et al., (1999), tipe mediasi restriktif adalah tipe saat orang tua menerapkan berbagai set aturan untuk menggunakan atau melarang anak melihat program tertentu. Bentuk tipe mediasi restriktif dilakukan dengan memberikan peraturan yang rasional (Fikkers et al., 2017). Tipe mediasi restriktif menerapkan aturan yang harus dipatuhi anak terkait waktu dan konten dalam menggunakan media. Kapan anak boleh mengakses internet, berapa lama waktu yang diberikan, permainan apa yang boleh dimainkan, konten apa yang boleh diakses, dan sebagainya. Orang tua yang beranggapan internet berdampak negatif, menimbulkan ketakutan dan sifat agresif bagi anaknya cenderung menerapkan tipe mediasi restriktif (Fikkers et al., 2017; Krassowski et al., 1999; Nikken \& Schols, 2015)controlling, or inconsistent. Meski demikian, sejumlah literatur melaporkan tipe mediasi restriktif memiliki pengaruh yang kecil namun signifikan untuk menghalau efek negatif dalam hal waktu penggunaan dan pengaruh konten seksual (Collier et al., 2016; Leung \& Lee, 2012). Pada banyak kasus, tipe mediasi restriktif menimbulkan efek bumerang, resistensi, atau inkonsisten baik dari anak maupun orang tua sendiri (Fikkers, Piotrowski, \& Valkenburg, 2017). Orang tua tidak konsisten dalam menerapkan aturan terutama dalam pemberian teladan. Sedangkan anak beranggapan mediasi membatasi aktivitasnya sehingga cenderung mengabaikan orang tua (Livingstone et al., 2011). Tipe mediasi restriktif dipengaruhi oleh kemampuan anak dalam menerapkan kontrol pribadi (Lee, 2013).

Tipe mediasi yang dinilai efektif untuk dilakukan adalah tipe mediasi aktif dan tipe mediasi teknis (Livingstone \& Helsper, 2008). Tipe mediasi aktif menunjukkan perilaku orang tua dalam menjelaskan dan mendiskusikan sebuah program (Krassowski et al., 1999)an outsider. Diskusi ini bertujuan untuk membangun kemampuan berpikir kritis pada anak tentang program atau konten yang dikonsumsinya (Collier et al., 2016). Diskusi interaktif antara orang tua dan anak terjalin sebagai komunikasi dua arah. Orang tua membimbing anak untuk menjadi pengguna media yang kritis (Livingstone \& Helsper, 2008). Jenis tipe mediasi aktif dilaporkan cukup protektif melindungi anak dari kerentanan pengaruh negatif, agresi, dan seksualitas tetapi tidak untuk waktu penggunaan media. Tipe mediasi couse atau penggunaan bersama merupakan tipe ketika orang tua dan anak secara bersama melihat atau menggunakan media bersama. Valkenburg et al., (1999) menilai tipe ini tidak benar-benar dilakukan untuk melindungi anak dari impak negatif media tetapi sebagai bentuk hiburan keluarga untuk menghabiskan waktu bersama. Orang tua akan menegur anak ketika ada perilaku menyimpang tetapi proses peneguran atau diskusi tidak dilakukan saat menonton bersama. Saat penggunaan bersama, orang tua juga menikmati bersama anak (Kaloka, 2016). Di era media baru, ketika perangkat media dapat dipersonalisasi, tipe co-use cenderung sulit diimplementasikan dan tidak efektif (Livingstone et al., 2011). Sedangkan tipe mediasi teknis menunjukkan upaya orang tua untuk menyaring dan mengontrol konten yang dikonsumsi anak melalui berbagai kumpulan tindakan teknis (Livingstone \& Helsper, 2008). Dari ragam tipe mediasi, Leung \& Lee (2012) menilai memblokir kunjungan ke situs media sosia dan hiburan lebih efektif $2-5 \%$ melindungi anak dibanding tipe mediasi lain.

Dalam implementasinya, tipe mediasi yang diterapkan orang tua dapat beragam dan kombinasi sesuai dengan kemampuan dan pengalaman mereka. Tingkat pendidikan mempengaruhi tipe mediasi yang diterapkan. Valkenburg et al., (1999) menemukan orang tua dengan pendidikan tinggi lebih menggunakan tipe mediasi restriktif dan aktif. Orang tua dengan pendidikan rendah cenderung membiarkan penggunaan gawai dan internet oleh anak tanpa peraturan (Nikken \& Schols, 2015). Usia dan keterampilan anak pun mempengaruhi 
tipe mediasi yang diterapkan. Hal ini berkaitan dengan kemampuan anak dalam menggunakan gawai dan beraktivitas online (Livingstone et al., 2017; Nikken \& Schols, 2015). Anak yang telah piawai menggunakan gawai dan berinternet akan menghabiskan waktu penggunaan lebih lama dan menyendiri atau asyik dengan dunia maya (Nikken \& Schols, 2015). Adanya perbedaan tipe mediasi ini salah satunya dipengaruhi oleh pemahaman dan tingkat literasi digital, khususnya orang tua (Kaloka, 2016; Livingstone et al., 2017; Nikken \& Haan, 2015).

Orang tua cenderung merasa tidak kompeten untuk menerapkan tipe mediase. Menurut Nikken dan Haan., (2015), orang tua tidak memiliki kecukupan literasi dan tidak mencari informasi dari sumber professional dalam upaya mediasi. Padahal, kemampuan literasi sangat dibutuhkan untuk menerapkan berbagai strategi mediasi (Lee, 2013). Status sosial dan ekonomi orang tua dapat mempengaruhi kemampuan literasinya. Literasi media informasi adalah kemampuan untuk mengakses, mengevaluasi, memahami, dan menggunakan berbagai media informasi. Leungdan Lee (2012) memaparkan setidaknya orang tua perlu memiliki kemampuan literasi tentang perangkat atau media, literasi kritis, literasi publikasi, literasi adaptasi teknologi, dan literasi struktur sosial sehingga dapat memediasi anak. Semakin kompeten orang tua terhadap konten media dan aplikasi intenet, maka semakin mampu ia menghalau efek buruk internet.

Ketidakpercayaan diri orang tua dalam menggunakan gawai dan berinternet di hadapan anaknya dapat disebabkan karena perbedaan generasi. Grail Research dalam memetakan generasi tidak hanya berdasarkan tahun kelahiran tetapi juga kemampuannya dalam mengadopsi teknologi. Meski keduanya tidak dapat saling terkait. Generasi dipetakan mulai dari generasi baby boomers hingga generasi alpha. Namun, isu tentang kesenjangan generasi di era TIK dimulai sejak generasi $\mathrm{X}$ atau latchey kids. Generasi X terlahir di tahun 196oan yang telah mengenal teknologi informasi, komputer bukan barang aneh bagi mereka. Akan tetapi, generasi X tidak dapat cepat mengadopsi teknologi baru. Tidak seperti generasi Y dan generasi Z. Generasi ini merupakan generasi post millineal, digital native, net generation, dan iGeneration. Generasi digital native menggunakan bahasa komputer, video games, dan internet serta cepat mengadopsi teknologi maju (Prensky, 2001). Mereka memahami internet, menjadi lebih cerdas dalam menggunakan teknologi terbaru. Karakteristik generasi $\mathrm{Z}$ adalah digitalisasi, akrabdengan perangkat bergerak, interaktif, menyukai hal (informasi) instan, berkomunikatas, mampu melakukan multi tugas.

\section{METODE}

Upaya melihat literasi TIK dan tipe mediasi orang tua terhadap aktivitas anak menggunakan dan mengakses internet dilakukan melalui deskriptif kuantitatif. Pengumpulan data dilaksanakan bersamaan dengan kegiatan fasilitasi layanan TIK bagi ibu rumah tangga di Kab. Kulonprogo, Kab. Gunungkidul, Kab. Sleman, dan Kab. Bantul. Kegiatan fasilitasi berlansung atas kerja sama antara Balai Pengkajian dan Pengembangan Komunikasi dan Informatika (BPPKI) Yogyakarta dan Dinas Komunikasi dan Informatika setempat. Tema yang diangkat dalam kegiatan tersebut adalah Workshop e-Safety Parenting: Mengasuh dan Mendampingi Anak di Era Digital. Subjek penelitian adalah ibu rumah tangga dengan anak berusia maksimal 17 tahun. Ibu dipilih karena memiliki peran penting dalam pendidikan dan pembentukan karakter anak sejak dini. Ibu dinilai lebih menerapkan tipe mediasi pada anak dibandingkan ayah (Livingstone et al., 2017). Sebuah kuesioner diberikan sebelum dan setelah pelatihan. Data deskriptif kuantitatif ini didukung pula dengan data hasil dari proses diskusi selama kegiatan berlangsung.

Kerangka berpikir merujuk pada literasi media baru yang dikembangkan Leung dan Lee (2012). Literasi media baru 
bertujuan untuk mengetahui pengetahuan dan kemampuan ibu rumah tangga dalam menggunakan TIK seperti keterampilan komputer, internet, dan penggunaan aplikasi layanan bergerak. Literasi pada penelitian ini hanya mengambil bagian penggunaan perangkat dan kemampuan publikasi konten sederhana. Sedangkan tipe mediasi media baru yang diterapkan di keluarga merujuk pada Livingstone \& Helper (2008), Leung et al., (2012), Nikken et al., (2015), dan Fikkers et al., (2017). Tipe mediasi dijabarkan dalam suatu bentuk aktivitas berdasarkan persepsi terhadap pengertian tiap tipe mediasi seperti terlihat pada Tabel 1.

\section{HASIL DAN PEMBAHASAN}

Partisipan dalam Workshop e-Safety Parenting sekaligus responden penelitian adalah ibu rumah tangga (IRT) yang memiliki anak maksimal berusia SMA (17 tahun). Mereka adalah IRT yang aktif dalam berbagai kegiatan sosial kemasyarakatan seperti pengurus PKK, kader kesehatan, dan penggerak aktivitas lainnya. Sebelum kegiatan workshop berupa ceramah, diskusi, dan pelatihan penggunaan TIK untuk mendampingi anak dilaksanakan, IRT diberi kuesioner tentang literasi media, penggunaan TIK di rumah, dan perilaku atau sikap mediasi yang diterapkan. Dari 119 kuesioner yang dibagikan, ada 110 kuesioner yang dapat diolah sesuai dengan persyaratan.

Tabel 2 menunjukkan profil responden IRT peserta pelatihan. Sebanyak 54,81\% IRT berpendidikan tertinggi SMA dan $27,88 \%$ berpendidikan tertinggi $\mathrm{D}_{4} / \mathrm{S}_{1}$. Usia IRT cukup merata mulai dari 35 tahun hingga di atas 45 tahun. Hanya 9,62\% IRT berusia di bawah 30 tahun. Kondisi ini menunjukkan kesenjangan generasi yang cukup lebarantara ibu dan anak seperti yang didukung Tabel 3. Tidak hanya berbeda generasi berdasarkan teori Prensky di mana anak terlahir sebagai digital native yang terbiasa dengan bahasa digital komputer, internet, dan perangkat TIK lainnya, tetapi juga berbeda menurut teori generasi Strauss dan Howe. Sebagian besar IRT merupakan generasi X atau latchey kids yang baru saja mengenal TIK. Mereka dapat beradaptasi dengan perkembangan TIK tetapi tidak mampu mengadopsinya dengan keterampilan yang baik. IRT memerlukan pembelajaran berulang untuk dapat benar-benar menggunakan dan tidak memiliki kemampuan atau keinginan untuk menjelajah lebih jauh. Meski demikian, masih terdapat IRT yang berasal dari generasi $\mathrm{Y}$ atau generasi pertama digital native yang masih gagap terhadap teknologi dan aplikasi IoT. Namun, anak-anak mereka merupakan generasi $\mathrm{Z}$ atau iGen yang lahir dalam perkembangan teknologi sosial serta terbiasa dengan teknologi multi tugas.

Perbedaan generasi ini dapat terlihat dari literasi perangkat (tools literacy) IRT seperti pada Grafik 1. IRT dapat menggunakan komputer dan mengakses internet baik melalui komputer maupun telepon pintar. Sebanyak 70,19\% IRT telah mampu menggunakan internet di telepon pintar dan 50,95\% dapat menggunakan internet di komputer. Dengan kemampuannya tersebut, $65,38 \%$ IRT dapat mengunduh gambar/ foto/video/dokumen dan $71,15 \%$ dapat pula mengunggahnya. Hal ini memperlihatkan IRT cukup aktif dalam mengakses media sosial. IRT telah familiar dengan berbagai media sosial dan aplikasi percakapan sosial seperti Facebook, Instagram, Whatsapp, dan Line. Whatsapp merupakan aplikasi percakapan sosial yang banyak digunakan IRT. Mereka lebih senang berkirim teks dan berkomunikasi melalui Whatsapp dibanding SMS atau telepon karena dinilai lebih murah, responsif, dan dapat disertai foto/ gambar/video. Situasi yang menunjukkan IRT merupakan generasi $\mathrm{X}$ dan generasi $\mathrm{Y}$ adalah kemampuan dalam menginstal aplikasi di telepon pintar dan penelusuran kembali. Ini merupakan sebuah kemampuan sederhana. Hanya 46,15\% IRT mengaku dapat memasang aplikasi dengan baik dan 43,27\% melaporkan dapat mengecek daftar website yang pernah dikunjungi. Akan tetapi, ketika ditanya dimana dan bagaimana prosesnya, banyak IRT yang menggelengkan kepalanya. IRT tidak dapat menunjukkan prosesnya dan tidak tahu apa itu playstore. IRT mengaku, 
Tabel 1. Perilaku Mediasi Berdasarkan Tipe Mediasi

\begin{tabular}{|c|c|c|}
\hline TIPE MEDIASI & $\mathrm{NO}$ & PERILAKU MEDIASI YANG DITERAPKAN \\
\hline \multirow[t]{3}{*}{ Restrictive Mediation } & $\mathrm{MED}_{1}$ & $\begin{array}{l}\text { Saya menetapkan aturan waktu yang diperbolehkan anak untuk } \\
\text { menggunakan telepon pintar/tablet }\end{array}$ \\
\hline & $\mathrm{MED}_{2}$ & $\begin{array}{l}\text { Saya menetapkan aturan waktu yang diperbolehkan anak untuk } \\
\text { mengakses internet }\end{array}$ \\
\hline & MED 6 & $\begin{array}{l}\text { Anak saya meminta izin jika ingin mengunduh dan menginstal } \\
\text { aplikasi di telepon pintar/tablet }\end{array}$ \\
\hline \multirow[t]{3}{*}{ Active Mediation } & MED 5 & Saya mencari informasi website dan aplikasi yang baik untuk anak \\
\hline & $\mathrm{MED}_{7}$ & Saya tahu aplikasi di telepon pintar/tablet yang digunakan anak \\
\hline & MED 10 & $\begin{array}{l}\text { Saya sering berdiskusi dengan anak tentang internet (konten di } \\
\text { internet) }\end{array}$ \\
\hline \multirow[t]{3}{*}{ Co-Use/ Co-Viewing } & $\mathrm{MED}_{3}$ & $\begin{array}{l}\text { Saya mendampingi anak ketika menggunakan telepon pintar/ } \\
\text { tablet }\end{array}$ \\
\hline & $\mathrm{MED}_{4}$ & Saya mendampingi anak ketika berinternet \\
\hline & MED 12 & $\begin{array}{l}\text { Saya memastikan telepon pintar/tablet orang tua layak digunakan } \\
\text { anak (bersih dari konten tidak baik) }\end{array}$ \\
\hline \multirow[t]{3}{*}{ Technical Mediation } & MED 8 & Saya tahu website yang sering dikunjungi anak \\
\hline & $\mathrm{MED}_{9}$ & Saya mengecek website yang dikunjungi anak \\
\hline & MED 11 & $\begin{array}{l}\text { Saya menginstal aplikasi filtering dan monitoring di telepon pin- } \\
\text { tar/tablet }\end{array}$ \\
\hline
\end{tabular}

Tabel 2. Profil Responden Ibu Rumah Tangga

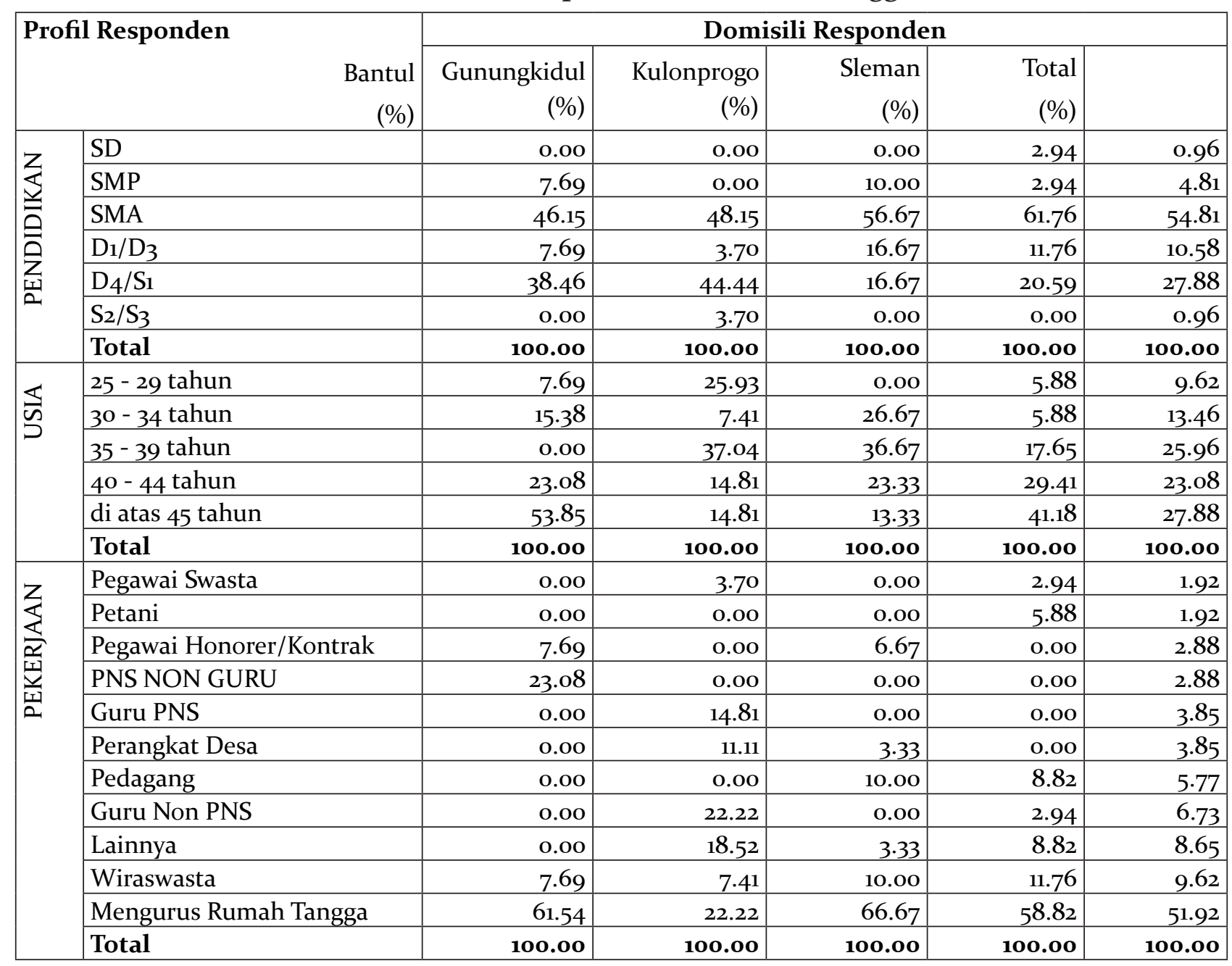


aplikasi yang ada telah tersedia sejak dibeli dan atau di-instal oleh anak.

Ditinjau dari kepemilikan dan penggunaan gawai oleh anak, sebanyak 6o,58\% anak telah memiliki gawai dan $45,19 \%$ anak menggunakan gawai milik orang tuanya. Sebarannya cukup merata di seluruh lokasi responden kecuali di Kab. Gunungkidul. Persentasenya lebih sedikit yaitu $44,44 \%$ anak yang memiliki gawai dan 29,63\% anak yang menggunakan gawai miliki orang tua. Namun untuk Kab. Sleman, terdapat $76,47 \%$ anak yang telah memiliki gawai. Lebih tingggi dibanding kabupaten lainnya. Menurut penuturan IRT, anak telah memiliki gawai sejak usia SD atau saat kelas 3. Pertimbangannya, orang tua tidak ingin anaknya tidak percaya diri dalam pergaulan, tidak dapat mengenal teknologi sejak dini, dan sekedar untuk memenuhi keinginan anak. Pemberian gawai kepada anak tidak disertai dengan pemberian konsep tentang dampak baik dan buruk penggunaan gawai serta internet dan tanggung jawab anak dalam penggunaanya. Demikian pula sikap dan perilaku orang tua saat meminjamkan gawai ke anak. Ada orang tua yang memberikan batasan waktu serta aplikasi yang boleh digunakan anak dan ada pula yang tidak. Ada orang tua yang memastikan konten di gawainya layak diketahui anak baik secara sengaja maupun tidak. Namun, tidak sedikit pula orang tua yang mengabaikan dan justru menyuruh anak menggunakan gawai agar aktivitas yang sedang dilakukan tidak terganggu. Sikap dan perilaku IRT inilah yang akan menunjukkan tipe mediasi yang digunakan.

Dari penelusuran terhadap perilaku peserta workshop, IRT dominan menerapkan tipe mediasi restriktif dibanding tipe mediasi lainnya. Terlihat pada Grafik 3. IRT menerapkan aturan waktu yang diperbolehkan anak untuk menggunakan gawai $(63,46 \%)$ dan mengakses internet $(55,77 \%)$ dan meminta anak untuk ijin ketika mengunduh dan memasang aplikasi di telepon pintar $(44,23 \%)$. IRT menerapkan sejumlah peraturan terutama tentang kapan waktu anak boleh menggunakan dan mengakses internet. Menurut IRT, anak diijinkan menggunakan gawai saat akhir pekan atau setelah belajar. Sedangkan aturan ijin untuk mengunduh dan memasang

Tabel 3. Peta Generasi IRT dan Anaknya

\begin{tabular}{|c|c|c|c|c|c|c|c|c|}
\hline \multicolumn{9}{|c|}{ GENERASI X } \\
\hline & & \multicolumn{3}{|c|}{ GENERASI Y } & & & & \\
\hline & & & & \multicolumn{5}{|c|}{ GENERASI Z } \\
\hline \multicolumn{5}{|c|}{ Ibu Rumah Tangga } & & & & \\
\hline 31 & 25 & 29 & 15 & 11 & \multirow{2}{*}{\multicolumn{4}{|c|}{ iGeneration (Generasi IoT) }} \\
\hline \multirow[t]{2}{*}{$<1972$} & $1973-$ & $1978-$ & $1983-$ & $1988-$ & & & & \\
\hline & & & & & \multirow{2}{*}{\multicolumn{4}{|c|}{ Anak dan Remaja }} \\
\hline & & & & & & & & \\
\hline & & & & & 20 & 15 & 39 & 39 \\
\hline & & & & & $\begin{array}{l}2000- \\
2002\end{array}$ & $\begin{array}{l}2002- \\
2004\end{array}$ & $\begin{array}{l}2004- \\
2010\end{array}$ & $\begin{array}{l}2010- \\
2017\end{array}$ \\
\hline
\end{tabular}




\section{LITERASI DIGITAL PADA IBU RUMAH TANGGA}

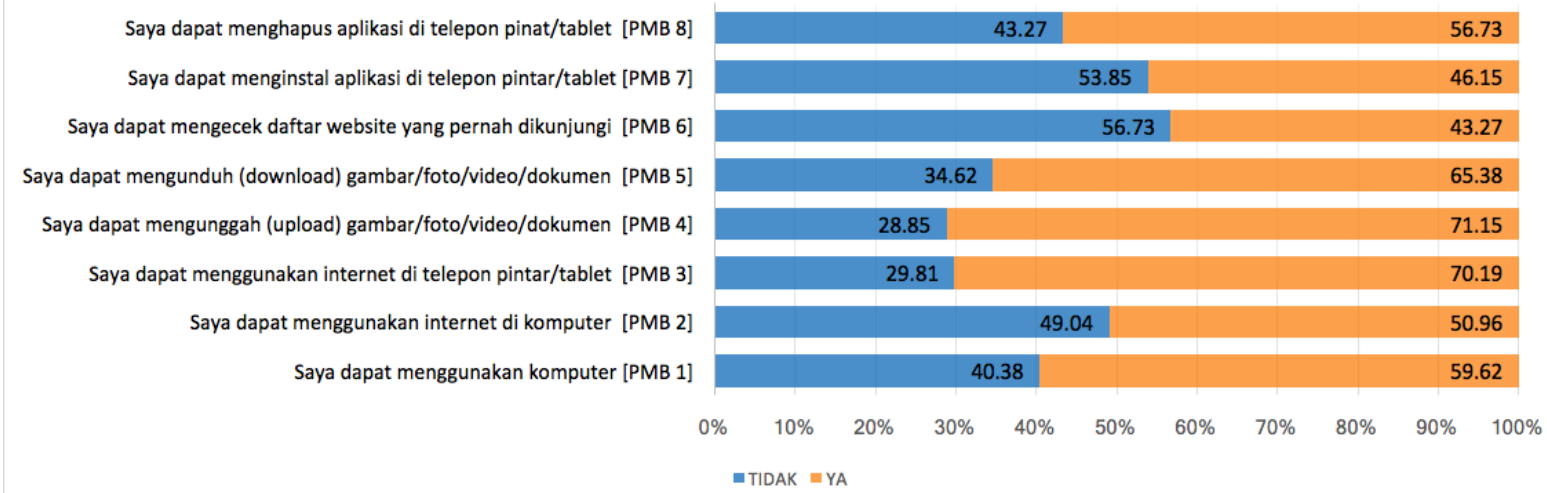

Grafik 1. Grafik Literasi Responden

Kepemilikan dan Penggunaan Gawai Oleh Anak

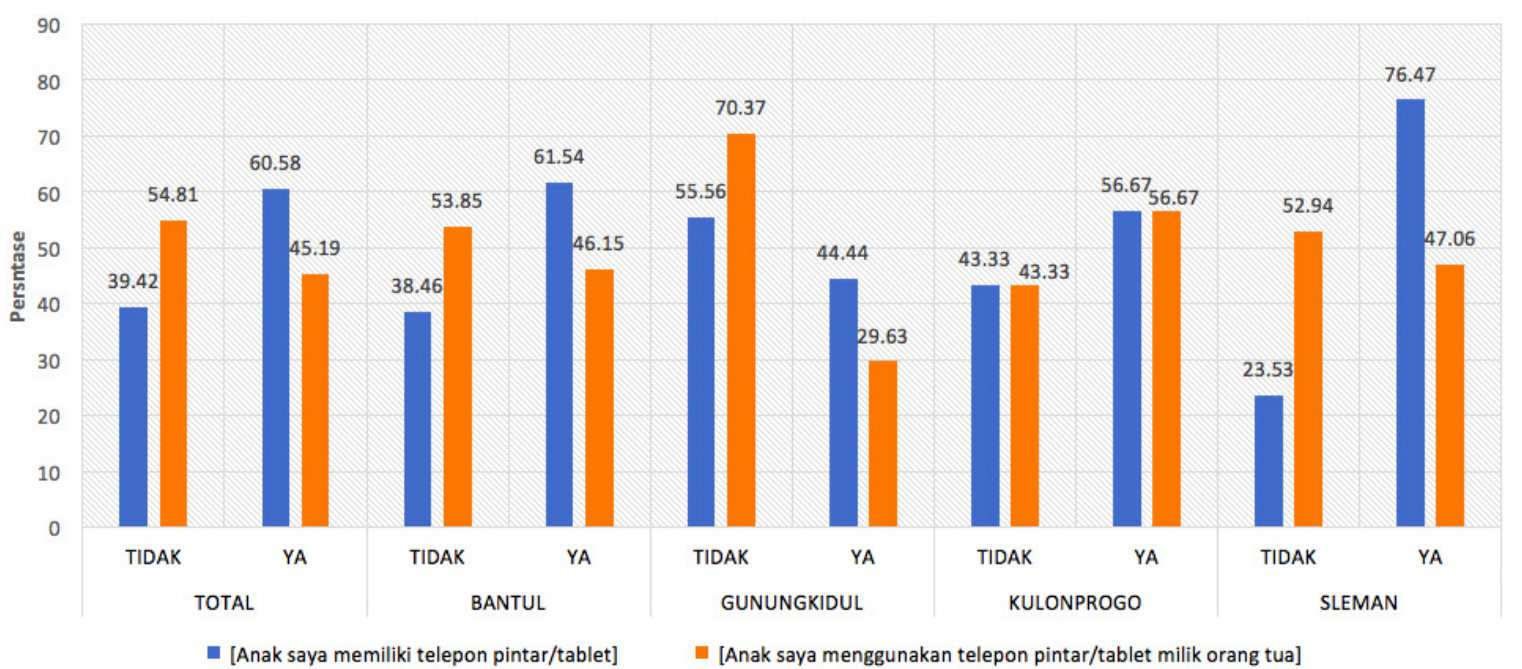

Grafik 2. Grafik Kepemilikan dan Penggunaan Gawai Oleh Anak Responden

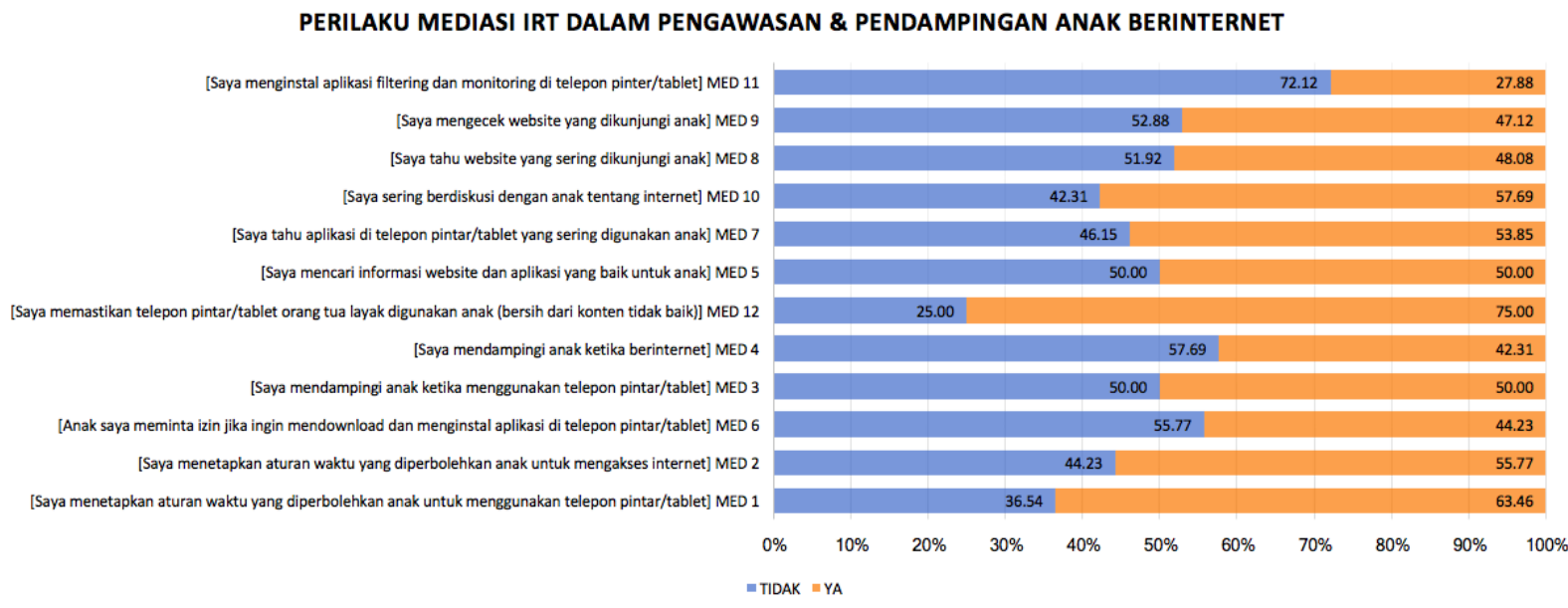

Grafik 3. Tipe Mediasi Responden IRT dalam Pengawasan dan Pendampingan Anak Berinternet 
aplikasi, bertujuan untuk mengatur kuota data internet dan kapasitas memori yang tersedia. Aturan ijin tidak benar-benar dilakukan untuk mengetahui aplikasi yang dapat digunakan anak atau tidak. Aturan penggunaan gawai dan internet dimotivasi oleh faktor kesehatan dan perilaku belajar anak. Orang tua mengkhawatirkan terhambatnya aktivitas belajar dan prestasi anak dari penggunaan gawai serta internet yang berlebihan sehingga menerapkan tipe mediasi restriktif. Pemahaman tentang dampak negatif seperti yang digambarkan Fikkers et al., (2017) dan Nikken dan Schols (2015) belum menjadi pendorong orang tua menerapkan mediasi restriktif.

Tipe mediasi co-use atau co-viewing relatif tidak banyak diterapkan. Hanya $42,31 \%$ IRT yang mendampingi anak keti$\mathrm{ka}$ mengakses internet dan $50 \%$ yang mendampingi anak ketika menggunakan gawai. Temuan ini menunjukkan anak lebih sering sendirian ketika aktif menggunakan gawai dan berinternet. IRT beranggapan anak hanya menggunakan aplikasi yang terpasang dan hanya mengakses Youtube. Untuk Youtube, IRT berkeyakinan anak hanya menonton kartun atau konten permainan yang biasa dimainkan. IRT tidak menyadari bahwa aplikasi yang terpasang cenderung bebas biaya sehingga dapat disisipi iklan. Tidak sedikit iklan yang muncul tidak layak dilihat anak. Apalagi konten di Youtube, meski kemasannya kartun maupun permainan. Dari proses diskusi, diketahui ada beberapa IRT yang menemukan konten tidak layak anak padahal itu adalah kartun permainan yang digemari anaknya. IRT tidak memiliki ketertarikan dengan apa yang digunakan, dilihat, dan diakses anak sehingga cenderung membiarkan anak sendirian. Keadaan menjadi lebih pelik ketika anak telah beranjak remaja dan aktif menggunakan media sosial. IRT merasa kesulitan untuk memantau anaknya dan merasa itu adalah bagian dari privasi anak. Temuan ini senada dengan Valkenburg et al., (1999) meski media yang digunakan adalah TV. Saat menonton TV bersama, orang tua menganggapnya sebagai family time (waktu keluarga) bukan bagian dari proses mediasi co-use. Apalagi dengan media baru seperti gawai dan internet di mana penggunaanya bersifat personal. Meski demikian, 75\% IRT memastikan gawai yang dipinjamkan ke anak bebas dari konten tidak layak anak. Terutama dari aplikasi dan foto/gambar/ video yang tersimpan akibat dari aktivitas bermedia sosial para IRT. IRT tidak dapat memungkiri bahwa mereka terlibat dalam banyak percakapan grup sehingga tidak dapat membendung informasi yang masuk baik itu teks, gambar, maupun video. Masih banyak IRT yang belum tahu dan tidak mengatur ulang aplikasi percakapan untuk tidak otomatis mengunduh konten. Untuk meyakinkan gawai mereka layak digunakan anak, IRT harus menghapus satu persatu konten tersebut.

Pada strategi tipe mediasi aktif, 57,60\% IRT mengaku sering berdiskusi dengan anak tentang internet. Tentang dampak baik dan buruk berinternet serta apa yang boleh dan tidak boleh dilakukan oleh anak. IRT pun berupaya mencari informasi website dan aplikasi yang baik untuk anaknya (50\%). Temuan ini sedikit menyanggah Nikken dan Haan (2015). Orang tua masih mencari informasi dari sumber profesional kendati jumlahnya tidak banya. Tidak sedikit pula IRT yang tahu aplikasi di gawai yang digunakan oleh anak, yaitu sebesar 53,85\%. Sebagian besar aplikasi yang diketahui IRT adalah permainan yang dimainkan anak seperti Clash of Clan, Plant vs Zombie, Pau, Subway Surfer, dan sebagainya. Pengetahuan IRT tentang penggunaan aplikasi cenderung berlaku untuk anak usia pra-remaja. Sedangkan untuk anak remaja, IRT tidak mengetahui aplikasi apa yang digunakan. IRT merasa kesulitan untuk mengecek gawai milik anak remaja karena dikunci dengan sandi tertentu. Hal ini senada dengan Livingstone et al., (2017) dan Nikken dan Schols (2015), anak usia remaja yang telah piawai dalam menggunakan gawai dan menjelajah internet akan cenderung asyik dengan dunia maya. Sifat gawai yang personalisasi semakin menyulitkan orang tua untuk memantau anaknya. 
Tipe mediasi yang tidak banyak diterapkan adalah tipe mediasi teknis. Terdapat $48,08 \%$ IRT yang tahu website atau konten yang sering dikunjungi atau dilihat anak dan 47,12\% yang mengecek website atau konten yang dikunjungi anak. IRT tidak mengetahui bagaimana cara melihat riwayat tontonan (di Youtube) dan riwayat laman website yang dikunjungi anak. Kemudian, hanya 27,88\% IRT yang mengaku memasang aplikasi parental control terutama untuk gawai yang digunakan bersama anak. Tidak banyaknya penerapan mediasi teknis dilatarbelakangi oleh ketidakcukupan literasi digital yang dimiliki IRT. Banyak IRT yang belum mengenal aplikasi parental control terutama untuk gawai yang digunakan bersama atau dipinjamkan ke anak. IRT tidak mengetahui bahwa parental control dapat membantu ibu dalam mengawasi waktu penggunaan gawai dan internet serta konten atau aplikasi yang boleh digunakan anak.

Dari persebaran lokasi IRT, tidak ada perbedaansignifikan terkait tipe mediasiyang diterapkan kecuali untuk Kab. Gunungkidul dan Kab. Sleman. Meski didominasi oleh IRT usia muda yang familiar dengan penggunaan gawai cerdas, terlihat IRTnya cenderung lebih menerapkan tipe mediasi restriktif. Hanya sebagian kecil IRT yang mendampingi anak ketika menggunakan gawai atau mengakses internet sebagai bentuk dari tipe mediasi co-use. Atau, berdiskusi dan mengetahui aktivitas anak sebagai strategi tipe mediasi aktif. Maupun mengecek dan menelusuri kembali riwayat kunjungan dan tontonan anak sebagai penerapan strategi mediasi teknis. Aktivitas tipe mediasi IRT secara menyeluruh di lokasi responden dapat dilihat pada Tabel 4 .

Tingkat pendidikan IRT mempengaruhi tipe mediasi yang digunakan meski perbedaanya tidak terlalu kentara seperti tampak pada Grafik 5. IRT yang berpendidikan lebih rendah lebih menerapkan tipe mediasi restriktif dibanding IRT berpendidikan tinggi. IRT yang berpendidikan tinggi lebih menerapkan tipe mediasi teknis. Temuan ini berbeda dengan Valkenburg et al., (1999) dan Nikken \& Schols (2015). IRT berpendidikan tinggi lebih cakapatau memiliki kemampuan literasi digital yang lebih baik dibanding IRT berpendidikan rendah.

Perbedaan tipe mediasi yang diterapkan terlihat juga pada jenjang pendidikan anak. IRT menerapkan seluruh kombinasi tipe mediasi untuk anak pada jenjang pendidikan rendah atau praremaja. IRT tidak hanya memberikan aturan penggunaan gawai dan inter-net sebagai bentuk mediasi restriktif tetapi juga mengajak anak berdiskusi (mediasi aktif) dan mendampingi anak saat beraktivitas (mediasi co-use). Sehingga, IRT dapat mengetahui konten atau website apa yang digunakan, dikunjungi, dan dilihat anak. Namun, untuk anak yang berpendidikan lebih tinggi atau telah remaja pada jenjang pendidikan SMP dan SMA, IRT terlihat tidak konsisten dalam menerapkan tipe mediasi tertentu atau kombinasinya. Ada saat IRT mengeluarkan aturan tentang waktu penggunaan gawai dan internet tetapi membebaskan anak untuk mengunduh atau memasang aplikasi di gawai. IRT tidak lagi mendampingi anak saat menggunakan internet sehingga mereka tidak tahu konten yang digunakan, dikunjungi, atau dilihat anak. IRT pun tidak mengecek apa yang telah digunakan anak. Kondisi ini terkait dengan tingkat literasi, kesenjangan yang jauh antara IRT dan anak remajanya. IRT merasa tidak memiliki kecukupan keterampilan yang memadai tentang teknologi, tidak memahami aplikasi atau media sosial yang digunakan anak, serta adanya keluhan tentang gawai anak yang disandi. Hal ini seperti diungkap Livingstone et al., (2011) yang mencatat anak usia 16 tahun telah aktif online dan menggunakan media sosial setiap minggunya. Meski terkendala tingkat literasi, IRT menunjukkan tipe mediasi aktif yang tinggi untuk upaya berdiskusi dengan anak tentang internet. IRT menggantikan upaya pengawasan dan perlindungan dengan sering berdiskusi pada anak efek baik dan buruk internet serta media sosial dengan harapan anak dapat terlindungi tetapi tidak merasa terkekang dengan pengawasan orang tua. 
Tabel 4. Aktivitas Tipe Mediasi IRT

\begin{tabular}{|c|c|c|c|c|c|c|c|c|c|c|c|}
\hline \multirow{2}{*}{$\begin{array}{c}\text { Aktivitas Mediasi Yang } \\
\text { Dilakukan }\end{array}$} & \multirow{2}{*}{ Tipe } & \multicolumn{2}{|c|}{ Total } & \multicolumn{2}{|c|}{ Bantul } & \multicolumn{2}{|c|}{ Gunungkidul } & \multicolumn{2}{|c|}{ Kulonprogo } & \multicolumn{2}{|c|}{ Sleman } \\
\hline & & TD & YA & $\mathrm{TD}$ & YA & $\mathrm{TD}$ & YA & TD & YA & TD & YA \\
\hline $\begin{array}{l}\text { [Saya menetapkan } \\
\text { aturan waktu yang } \\
\text { diperbolehkan anak } \\
\text { untuk menggunakan } \\
\text { telepon pintar/tablet] } \\
\text { MED 1 }\end{array}$ & \multirow{3}{*}{ 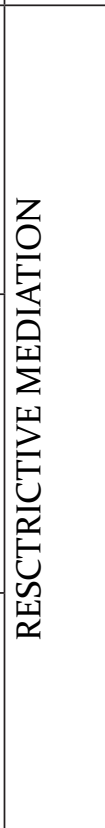 } & 36.54 & 63.46 & 15.38 & 84.62 & 51.85 & 48.15 & 16.67 & 83.33 & 50.00 & 50.00 \\
\hline $\begin{array}{l}\text { [Saya menetapkan } \\
\text { aturan waktu yang } \\
\text { diperbolehkan anak } \\
\text { untuk mengakses } \\
\text { internet] } \\
\text { MED } 2 \\
\end{array}$ & & 44.23 & $55 \cdot 77$ & 30.77 & 69.23 & 55.56 & 44.44 & 52.94 & 47.06 & 44.23 & $55 \cdot 77$ \\
\hline $\begin{array}{l}\text { [Anak saya meminta izin } \\
\text { jika ingin mendownload } \\
\text { dan menginstal aplikasi } \\
\text { di telepon pintar/tablet] } \\
\text { MED 6 }\end{array}$ & & $55 \cdot 77$ & 44.23 & 53.85 & 46.15 & 74.07 & $25 \cdot 93$ & 33.33 & 66.67 & 61.76 & 38.24 \\
\hline $\begin{array}{l}\text { [Saya mendampingi } \\
\text { anak ketika } \\
\text { menggunakan telepon } \\
\text { pintar/tablet] MED } 3\end{array}$ & \multirow{3}{*}{ 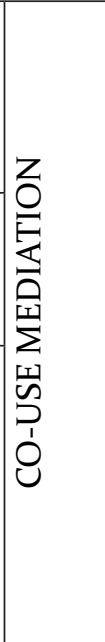 } & 50.00 & 50.00 & 38.46 & 61.54 & 70.37 & 29.63 & 23.33 & 76.67 & 61.76 & 38.24 \\
\hline $\begin{array}{l}\text { [Saya mendampingi } \\
\text { anak ketika berinternet] } \\
\text { MED } 4\end{array}$ & & 57.69 & 42.31 & 46.15 & 53.85 & 70.37 & 29.63 & 36.67 & 63.33 & 70.59 & 29.41 \\
\hline $\begin{array}{l}\text { [Saya memastikan } \\
\text { telepon pintar/ } \\
\text { tablet orang tua layak } \\
\text { digunakan anak (bersih } \\
\text { dari konten tidak baik)] } \\
\text { MED } 12\end{array}$ & & 25.00 & 75.00 & 23.08 & 76.92 & 37.04 & 62.96 & 10.00 & 90.00 & 29.41 & 70.59 \\
\hline $\begin{array}{l}\text { [Saya mencari informasi } \\
\text { website dan aplikasi yang } \\
\text { baik untuk anak] MED } 5\end{array}$ & \multirow{3}{*}{ 层 } & 50.00 & 50.00 & 23.08 & 76.92 & 62.96 & 37.04 & 30.00 & 70.00 & 67.65 & 32.35 \\
\hline $\begin{array}{l}\text { [Saya tahu aplikasi di } \\
\text { telepon pintar/tablet } \\
\text { yang sering digunakan } \\
\text { anak] } \\
\text { MED } 7\end{array}$ & & 46.15 & 53.85 & 46.15 & 53.85 & 62.96 & 37.04 & 20.00 & 80.00 & 55.88 & 44.12 \\
\hline $\begin{array}{l}\text { [Saya sering berdiskusi } \\
\text { dengan anak tentang } \\
\text { internet] } \\
\text { MED 1o }\end{array}$ & & 42.31 & 57.69 & 46.15 & 53.85 & 55.56 & $44 \cdot 44$ & 26.67 & 73.33 & 44.12 & 55.88 \\
\hline
\end{tabular}




\begin{tabular}{|c|c|c|c|c|c|c|c|c|c|c|c|}
\hline $\begin{array}{l}\text { [Saya tahu website yang } \\
\text { sering dikunjungi anak] } \\
\text { MED } 8\end{array}$ & Z & 51.92 & 48.08 & 53.85 & 46.15 & 62.96 & 37.04 & 23.33 & 76.67 & 67.65 & 32.35 \\
\hline $\begin{array}{l}\text { [Saya mengecek website } \\
\text { yang dikunjungi anak] } \\
\text { MED } 9\end{array}$ & 空 & 52.88 & 47.12 & 46.15 & 53.85 & 66.67 & 33.33 & 26.67 & 73.33 & 67.65 & 32.35 \\
\hline $\begin{array}{l}\text { [Saya menginstal } \\
\text { aplikasi filtering dan } \\
\text { monitoring di telepon } \\
\text { pinter/tablet] } \\
\text { MED } 11\end{array}$ & 岂 & 72.12 & 27.88 & 69.23 & 30.77 & 92.59 & 7.41 & 40.00 & 60.00 & 85.29 & 14.71 \\
\hline
\end{tabular}
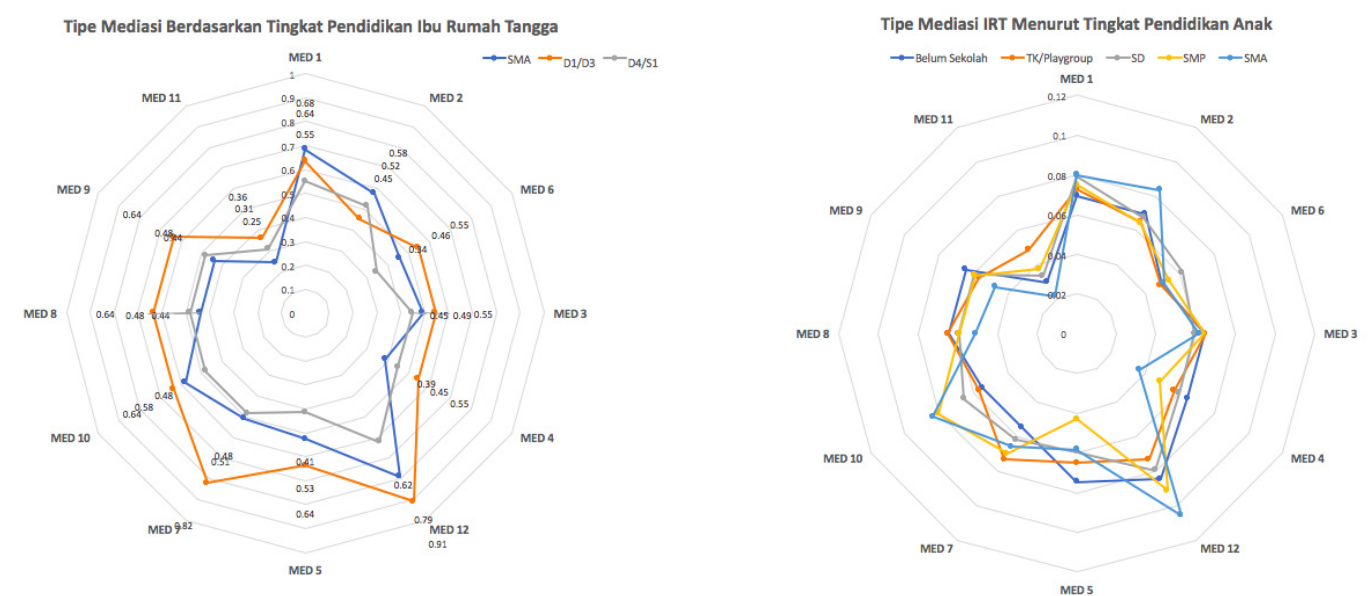

Grafik 4. Tipe Mediasi Menurut Tingkat Pendidikan IRT dan Tingkat Pendidikan Anak

\section{SIMPULAN}

Mediasi orang tua terhadap penggunaan gawai dan internet pada anak merupakan upaya untuk melindungi anak dari dampak negatif teknologi. Ibu merupakan aktor penting dalam penerapan tipe mediasi dalam keluarga. Tiap ibu rumah tangga menerapkan tipe mediasi yang berbeda sesuai dengan tingkat literasi yang dimiliki, tingkat pendidikannya, serta jenjang pendidikan anak. Perbedaan generasi antara ibu dan anak menimbulkan adanya kesenjangan tidak hanya keterampilan bermedia baru tetapi juga ketertarikan pada konten. Dalam penerapannya, ibu banyak memberikan aturan penggunaan gawai dan internet seperti kapan waktu yang diperbolehkan untuk menggunakan dan mengakses internet. Tipe mediasi restriktif diterapkan pada seluruh jenjang pendidikan anak dan tingkat literasi ibu rumah tangga. Meski demikian, ibu rumah tangga yang berpendidikan tinggi lebih menerapkan tipe mediasi teknis. Tipe mediasi aktif khususnya melakukan diskusi dengan anak tentang dampak baik dan buruk penggunaan gawai serta konten internet sering dilakukan ibu terutama untuk anak berjenjang pendidikan tinggi atau remaja. Ibu menyadari kemampuan literasinya tidak sama dengan anak sehingga mereka tidak dapat mengetahui, mengawasi, dan membatasi aktivitas anak berinternet. Upaya berdiskusi dinilai ibu lebih efektif untuk memberikan perlindungan bahaya internet bagi anak. Ibu tidak memiliki kemampuan teknis yang mendorong mereka melakukan mediasi teknis. Demikian pula pada strategi mediasi co-use atau penggunaan bersama. Ibu cenderung tidak mendampingi anak saat menggunakan gawai atau berinternet pada seluruh jenjang pendidikan anak. Sifat gawai yang personalisasi dan ubiquitoius menjadi pemicu tidak adanya penggunaan bersama atau pendampingan. 
Studi tentang tingkat literasi dan tipe mediasi ini hanya mengukur dari sisi ibu sebagai aktor yang melakukan mediasi. Belum mengukur dari sisi anak sebagai objek mediasi. Pengukuran dari sisi anak juga perlu dilakukan untuk mengetahui keefektifan dan tanggapan anak terhadap perilaku pengawasan dari orang tua. Hal ini penting untuk dilakukan karena seperti yang dinyatakan Livingstone et al., (2011) anak terpapar pengaruhi TIK tidak dari lingkungan rumah, tetapi dari pertemanan dan sekolah. Pengetahuan tentang keefektifan ini perlu juga dilakukan untuk mengetahui siapa sebenarnya yang dapat mempengaruhi anak dalam bermedia baru secara baik. Penelitian selanjutnya diharapkan dapat memasukkan permasalahan ini. 


\section{DAFTAR PUSTAKA}

Ameliola, S., \& Nugraha, H. D. (2013). Perkembangan Media Informasi dan Tekonologi Terhadap Anak dalam Era Globalisasi. The 5th International Conference on Indonesian Studies: "Ethnicity and Globalization"ity and Globalization”, 362-371.

Clark, L. S. (2011). Parental mediation theory for the digital age. Communication Theory, 21(4), 323-343. https://doi. org/10.1111/j.1468-2885.2011.01391.X

Collier, K. M., Coyne, S. M., Rasmussen, E. E., Hawkins, A. J., Padilla-Walker, L. M., Erickson, S. E., \& Memmott-Elison, M. K. (2016). Does parental mediation of media influence child outcomes? A meta-analysis on media time, aggression, substance use, and sexual behavior. Developmental Psychology, 52(5), 798-812. https://doi.org/10.1037/ devoooo108

Dorsey, J. (2016). iGen Tech Disruption: 2016 National Study on Technology and the Generation after Millennials, 4-33.

Fikkers, K. M., Piotrowski, J. T., \& Valkenburg, P. M. (2017). A matter of style? Exploring the effects of parental mediation styles on early adolescents' media violence exposure and aggression. Computers in Human Behavior, 70, 407-415. https:// doi.org/10.1016/j.chb.2017.01.029

Howe, N., \& Nadler, R. (2012). WHY GENERATIONS MATTER : Ten Findings from LifeCourse Research on the Workforce.

Kaloka, R.A. (2016). PARENTAL MEDIATION PADA ANAK SAAT MENONTON TELEVISI DENGAN RATING GUIDE BIMBINGAN ORANG TUA ( R-BO ). Jurnal Interaksi, 5(1), 62-67.

Krassowski, E., Plante, E., Windfuhr, K. L., Faragher, B., Conti-Ramsden, G. and B. N., Marton, K., ... Tomblin, J. B. (1999). Developing a scale to assess three styles of television mediation:
"Instructive mediation," "restrictive mediation," and "social coviewing." Journal of Broadcasting E Electronic Media, 43(1), 52-66. https://doi. org/10.1080/o8838159909364474

Kunandar, A. (2014). Model Literasi Media pada Anak dalam Mencegah Konflik Sosial. Profetik: Jurnal Komunikasi, 7(1), 87-99. Retrieved from http://ejournal. uin-suka.ac.id/isoshum/profetik/ article/view/1117/1030

Lee, S.-J. (2013). Parental restrictive mediation of children's internet use: Effective for what and for whom? New Media $\mathcal{E}$ Society, 15(4), 466-481. https://doi. org/10.1177/1461444812452412

Leung, L., \& Lee, P. S. N. (2012). The influences of information literacy, internet addiction and parenting styles on internet risks. New Media $\mathcal{E}$ Society, 14(1), 117-136. https://doi. org/10.1177/1461444811410406

Livingstone, S., Haddon, L., Görzig, A., \& Ólafsson, K. (2011). Risks and safety on the internet: the perspective of European children: full findings and policy implications from the EU Kids Online survey of 9-16 year olds and their parents in 25 countries, 170. https://doi. org/2045-256X

Livingstone, S., \&Helsper, E.J. (20o8). Parental mediation of children's internet use. Journal of Broadcasting and Electronic Media, 52(4), 581-599. https://doi. org/10.108o/o8838150802437396

Livingstone, S., Ólafsson, K., Helsper, E. J., Lupiáñez-Villanueva, F., Veltri, G. A., \& Folkvord, F. (2017). Maximizing Opportunities and Minimizing Risks for Children Online: The Role of Digital Skills in Emerging Strategies of Parental Mediation. Journal of Communication, 67(1), 82-105. https://doi.org/10.1111/ jcom.12277

Nikken, P., \& Haan, J. de. (2015). Guiding young children's internet use at home. Cyberpsychology: Journal of Psychosocial Research on Cyberspace, 
9(1). $\quad$ https://doi.org/http://dx.doi. org/10.5817/CP2015-1-3

Nikken, P., \& Schols, M. (2015). How and Why Parents Guide the Media Use of Young Children. Journal of Child and Family Studies, 24(11), 3423-3435. https://doi. org/10.1007/s10826-015-0144-4

Prensky, M. (2001). Digital Natives, Digital Immigrants Part 1. On the Horizon, 9(5), 1-6. Retrieved from https://doi. org/10.1108/10748120110424816

http://tekno.liputan6.com/read/2838968/ orang-tua-sering-lalai-bahayaaktivitas-online-anak-anak (220617)

https://www.kominfo.go.id/content/ detail/3834/siaran-pers-no17pihkominfo22014-tentang-risetkominfo-dan-unicef-mengenaiperilaku-anak-dan-remaja-dalammenggunakan-internet/o/siaran_pers

https:// www.cnnindonesia.com/ nasional/20150210171810-20-31101/ada1022-anak-menjadi-korban-kejahatanonline/ 